\title{
ETNOZOOLOGI SUKU DAYAK MAYAN UNTUK OBAT-OBATAN DI DESA MENSUSAI KECAMATAN SUHAID KABUPATEN KAPUAS HULU
}

\author{
(Ethnozoological of Dayak Mayan for Medecine in Mensusai Village Suhaid District \\ Kapuas Hulu Regency)
}

\author{
Friska Celly Aprillia, M. Sofwan Anwari, Hafiz Ardian \\ Fakultas Kehutanan Universitas Tanjungpura, JL. Daya Nasional Pontianak, 78124 \\ Email : friskacelly334@gmail.com
}

\begin{abstract}
Dayak Mayan is the only tribe in Mensusai Village, Suhaid District, Kapuas Hulu Regency. They utilize natural products in the form of animals or animals for daily needs such as consumption needs (protein), for traditional rituals, medication, mystical and commercial activities. Animals are used for medecine based on experience and tradition for generations. The research objective was to obtain data of animals species that used as medicine and to obtain data on the processing and usage of animals as medicine by the Dayak Mayan in Mensusai Village, Suhaid District, Kapuas Hulu Regency. The method used are survey method, respondents was selected by snowball sampling techniques and data collection using a questionnaire. Based on result research that there are 14 types of animals that are believed by the Dayak Mayan Community and are commonly used or used as medicine. Animal body parts that are used for treatment are thorns, flesh, bile, fur, blood, scales, fat, honey and skin. How to use it by being stuck in the river, eaten, drunk, taped to the broken part and smeared.
\end{abstract}

Keywords: Dayak Mayan Tribe, Ethnozoological, Medicine,

\section{PENDAHULUAN}

Suku Dayak Mayan merupakan satu-satunya suku yang berada di Desa Mensusai, Kecamatan Suhaid, Kabupaten Kapuas Hulu. Mereka memanfaatkan hasil alam berupa satwa atau hewan untuk keperluan sehari-hari seperti kebutuhan konsumsi (protein), keperluan ritual adat, pengobatan, kegiatan mistis dan komersial. Satwa juga bisa dimanfaatkan sebagai simbol kesenian dan pertanda menurut keyakinan setempat. Praktek pemanfaatan satwa telah dilakukan oleh sebagian besar suku Dayak Mayan di Kalimantan Barat untuk kebutuhan hidup sehari-hari terutama di Desa
Mensusai. Pengetahuan lokal suku Dayak Mayan di Desa Mensusai mengenai pemanfaatan hewan untuk obat masih banyak yang dipertahankan hingga saat ini. Oleh sebab itu, perlu dilakukan penelitian di Desa Mensusai, Kecamatan Suhaid, Kabupaten Kapuas Hulu untuk mengetahui tentang pemanfaatan hewan sebagai obat. Tujuan penelitian ini untuk mendapatkan data mengenai jenis satwa yang dimanfaatkan untuk obat dan memperoleh data mengenai cara pemanfaatan dan proses pengolahan atau penggunaan pada setiap jenis satwa untuk obat yang digunakan oleh suku Dayak Mayan di Desa Mensusai, 
Kecamatan Suhaid, Kabupaten Kapuas Hulu.

\section{METODE PENELITIAN}

Penelitian ini dilaksanakan di Desa Mensusai, Kecamatan Suhaid, Kabupaten Kapuas Hulu, dimulai pada tanggal 27 agustus 2019 sampai dengan tanggal 27 september 2019. Metode Pengumpulan data dilakukan dengan cara survey lapangan, wawancara serta pengamatan langsung di lapangan. Pemilihan responden ini dilakukan dengan menggunakan teknik snowball sampling, yaitu dengan menentukan responden kunci untuk kemudian menentukan responden lainnya berdasarkan informasi dari responden sebelumnya, demikian juga untuk seterusnya (Poerwandi, 1998). Responden kunci adalah orang yang memiliki pengetahuan luas mengenai jenis hewan, cara mendapatkannya, bagian yang digunakan, cara memanfaatkannya serta kegunaannya. Wawancara yang telah dilakukan, keterangannya harus dilakukan pencatatan yang lengkap mengenai keterangan jenis-jenis satwa yang dimanfaatkan oleh masyarakat setempat.
Analisa data dilakukan dengan cara deskripsi, yaitu menggambarkan atau menjelaskan hasil penelitian tersebut. Data hasil wawancara yang meliputi nama jenis (nama lokal dan ilmiah), manfaat untuk obat, cara memperoleh (teknik, alat dan waktu), cara pengolahan berdasarkan manfaatnya dibuat dalam bentuk tabulasi dan kemudian dideskripsikan.

\section{HASIL DAN PEMBAHASAN}

\section{Pemanfaatan Hewan untuk Pengobatan \\ Pemanfaatan hewan oleh} masyarakat Desa Mensusai tidak hanya sebagai bahan pangan tetapi juga dimanfaatkan untuk bahan pengobatan. Beberapa jenis penyakit yang dapat disembuhkan seperti penawar racun, kurang darah, penyakit dalam akibat jatuh, diabetes, asma, patah tulang dan sakit mata (petik), proses pemulihan setelah operasi, mengobati gigitan serangga, penyakit kulit (alergi) dan batuk. Pemanfaatan hewan untuk pengobatan mulai dari cara pengolahannya dan cara pemakaiannya sebagai obat dapat dilihat pada Tabel 1. 
Tabel 1. Pemanfaatan Hewan untuk Pengobatan oleh Masyarakat Dayak Mayan di Desa Mensusai Kecamatan Suhaid Kabupaten Kapuas Hulu (Animal ultilization for medecine by Dayak Mayan people in Mensusai Village, Suhaid District, Kapuas Hulu Regency)

\begin{tabular}{|c|c|c|c|c|c|c|c|}
\hline No & $\begin{array}{l}\text { Nama } \\
\text { Daerah }\end{array}$ & $\begin{array}{c}\text { Nama } \\
\text { Indonesia }\end{array}$ & Nama Ilmiah & $\begin{array}{c}\text { Bagian yang } \\
\text { Dimanfaatkan }\end{array}$ & $\begin{array}{c}\text { Jenis } \\
\text { Penyakit } \\
\end{array}$ & $\begin{array}{c}\text { Cara } \\
\text { Pengolahan }\end{array}$ & $\begin{array}{l}\text { Cara } \\
\text { Pemakaian }\end{array}$ \\
\hline 1 & Landak & Landak & Hystrix brachiura & Duri & $\begin{array}{c}\text { Untuk } \\
\text { dijadikan } \\
\text { penawar racun } \\
\text { tumbuhan } \\
\text { tuba }\end{array}$ & Durinya diambil & $\begin{array}{l}2 \text { Duri Landak ditancap masing- } \\
\text { masing disebelah sungai yang } \\
\text { sudah bercampur racun } \\
\text { tumbuhan tuba }\end{array}$ \\
\hline 2 & Asuk & Anjing & Canis lupus amiliaris & Daging & Kurang darah & $\begin{array}{c}\text { Dagingnya } \\
\text { dimasak }\end{array}$ & Dimakan \\
\hline 3 & Behuang & Beruang & Helarctos Malayanus & Empedu & $\begin{array}{c}\text { Untuk } \\
\text { mengobati } \\
\text { penyakit } \\
\text { dalam akibat } \\
\text { jatuh } \\
\end{array}$ & $\begin{array}{l}\text { Empedu } \\
\text { dikeringkan } \\
\text { (dijemur) }\end{array}$ & $\begin{array}{l}\text { Disedu dengan air hangat dan } \\
\text { langsung diminum }\end{array}$ \\
\hline 4 & Bunyak & Tupai & Tupaia spp & Daging & Diabetes & $\begin{array}{c}\text { Dagingnya } \\
\text { dimasak }\end{array}$ & Dimakan \\
\hline 5 & Engklawah & Kelelawar & $\begin{array}{l}\text { Megachiroptera } \\
\text { Microchiroptera }\end{array}$ & Daging & Asma & $\begin{array}{l}\text { Dagingnya } \\
\text { dimasak }\end{array}$ & Dimakan \\
\hline 6 & Manuk & Ayam & $\begin{array}{l}\text { Gallus gallus } \\
\text { domesticus }\end{array}$ & $\begin{array}{l}\text { Daging (anak } \\
\text { ayam) dan Bulu } \\
\text { Ayam }\end{array}$ & $\begin{array}{l}\text { Patah tulang } \\
\text { dan sakit mata } \\
\text { (petit) }\end{array}$ & $\begin{array}{c}\text { Dagingnya } \\
\text { dicincang dan } \\
\text { Bulu Ayam yang } \\
\text { masih berdarah } \\
\text { diambil }\end{array}$ & $\begin{array}{c}\text { Dagingnya ditempel ke bagian } \\
\text { yang patah dan darah yang ada } \\
\text { pada benjolan merah yang } \\
\text { terdapat dibagian luar belakang } \\
\text { tubuh tersebut dikeluarkan } \\
\text { kemudian dioles dengan darah } \\
\text { dari bulu ayam yang diambil } \\
\text { tersebut }\end{array}$ \\
\hline 7 & Ikan Delak & Gabus & Channa striata & Daging & $\begin{array}{c}\text { Untuk proses } \\
\text { pemulihan } \\
\text { setelah operasi }\end{array}$ & $\begin{array}{l}\text { Dimasak } \\
\text { (direbus) }\end{array}$ & Dimakan \\
\hline 8 & Belut & Belut & Monopterus albus & $\begin{array}{l}\text { Daging dan } \\
\text { Darah }\end{array}$ & Asma & $\begin{array}{c}\text { Dagingnya } \\
\text { dimasak dan } \\
\text { Darahnya } \\
\text { diambil } \\
\end{array}$ & $\begin{array}{l}\text { Dagingnya dimakan dan } \\
\text { Darahnya diminum mentah- } \\
\text { mentah }\end{array}$ \\
\hline 9 & Ikan Siluk & Arwana & $\begin{array}{l}\text { Scleropages } \\
\text { formosus }\end{array}$ & Sisik & $\begin{array}{l}\text { Mengobati } \\
\text { gigitan } \\
\text { serangga } \\
\end{array}$ & Sisiknya dibakar & $\begin{array}{l}\text { Dioles ke bagian yang digigit } \\
\text { serangga }\end{array}$ \\
\hline 10 & Bejawak & Biawak & Varanus salvator & Daging & $\begin{array}{l}\text { Gatal dan } \\
\text { Bisul } \\
\text { (penyakit } \\
\text { kulit) } \\
\end{array}$ & $\begin{array}{l}\text { Dimasak } \\
\text { (direbus) }\end{array}$ & Dimakan \\
\hline 11 & Ulah Sawak & Ular Pithon & Python reticulatus & Lemak & $\begin{array}{c}\text { Gatal dan } \\
\text { Korengan } \\
\text { (alergi) }\end{array}$ & Dijemur & Dioles \\
\hline 12 & $\begin{array}{l}\text { Ulah } \\
\text { Hipung }\end{array}$ & Ular Tedung & Ptyas korros & Daging & Gatal (alergi) & Dimasak & Dimakan \\
\hline 13 & Muanyik & Lebah Madu & Apis spp & Madu & $\begin{array}{c}\text { Untuk } \\
\text { mengobati } \\
\text { orang sakit } \\
\text { akibat jatuh } \\
\text { dan Batuk }\end{array}$ & $\begin{array}{l}\text { Diperas langsung } \\
\text { dari sarangnya }\end{array}$ & Diminum \\
\hline 14 & $\begin{array}{l}\text { Cacin } \\
\text { Tanah }\end{array}$ & $\begin{array}{l}\text { Cacing } \\
\text { Tanah }\end{array}$ & Lumbricus spp & Kulit & Asma & $\begin{array}{c}\text { Dimasak } \\
\text { (digoreng) }\end{array}$ & Dimakan \\
\hline
\end{tabular}

Terdapat 14 jenis hewan yang dipercaya oleh Masyarakat Dayak Mayan dan biasa dimanfaatkan atau dipergunakan sebagai obat yaitu :

a. Landak (Hystrix brachiura)
Bagian tubuh dari landak yang dimanfaatkan sebagai obat yaitu duri landak. Duri landak (Gambar 1) dipercaya oleh masyarakat Dayak Mayan sebagai penawar racun tuba. Tumbuhan tuba adalah jenis tumbuhan 
dimana bagian akarnya yang diambil dan dijadikan racun alami untuk menangkap dan mematikan ikan. Cara penggunaannya ujung 2 duri landak ditancap masing-masing disebelah sungai yang sudah bercampur racun tumbuhan tuba untuk menghilangkan racun yang terdapat pada sungai tersebut supaya airnya bersih dan bisa dimanfaatkan kembali seperti semula. Selain itu, duri landak dipercaya memiliki sifat analgesik, atau pereda rasa sakit dan juga diyakini dapat meningkatkan sistem kekebalan tubuh, serta memperbaiki jaringan tubuh yang rusak. Duri landak juga digunakan Masyarakat Dayak Seberuang di Desa Gurung Mali Kecamatan Tempunak Kabupaten Sintang untuk menyembuhkan penyakit yaitu sebagai obat masuk angin dan demam. Cara menggunakan duri tersebut dikikis dan dicampur dengan air dan dikumur lalu disemurkan ke bagian perut. Guna mengobati seseorang yang tengah dirasuki oleh makhluk halus, dapat menggosokkan duri landak ke bagian telapak kakinya atau telapak tangannya agar dapat pulih dengan mudah dan cepat. Duri landak merupakan jimat tradisional yang semakin langka.

Pemanfaatan usus oleh Masyarakat Dayak Belangin di Desa Mu'un dan Masyarakat Dayak Kanayant di Desa Babane dapat berkhasiat sebagai obat namun tidak semua usus dapat berkhasiat obat dan hanya hewan lanak atau landak saja yang usus halusnya dapat dimanfaatkan sebagai obat. Cara pengolahannya yaitu dengan menyimpan usus kecil yang masih terdapat sari-sari makanan di atas perapian atau dijemur agar kering sebagai upaya pengeringan untuk pengawetan. Pengolahan sebagai obat dengan mengambil usus yang sudah kering kemudian direbus atau direndam air panas. Penggunaannya dengan cara diminum, hal ini dipercaya dapat menyembuhkan tipes dan malaria. Salah satu responden menjelaskan geliga landak sangat mujarap dalam mengatasi berbagai jenis penyakit namun untuk mendapatkan geliga sangat sulit. Oleh sebab itu mereka memanfaatkan usus kecil yang dipercaya dapat berkhasiat sama dengan geliga landak. Pemanfaatan satwa sebagai obat tidak hanya bagian lemak satwa tetapi kotoran, kulit, daging, madu dan seluruh tubuh satwa. Kotoran landak yang dimanfaatkan masyarakat Dayak Bakati di Desa Seluas Kecamatan Seluas Kabupaten Bengkayang untuk mengobati keracunan makanan, mabuk minuman keras dan pegal-pegal pada tubuh. Cara pengolahannya terlebih dahulu kotoran landak dijemur sampai kering dan dicampurkan sedikit kedalam minuman apabila saat keracunan makanan, mabuk minuman keras dan pegal-pegal. 


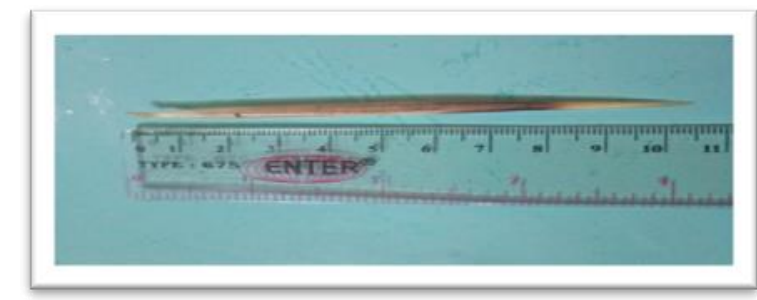

Gambar 1. Duri Landak (The Porcupine Spines)

\section{b. Anjing (Canis lupus familiaris)}

Anjing adalah hewan peliharaan masyarakat Dayak Mayan. Daging anjing dipercaya oleh masyarakat Dayak Mayan untuk mengobati orang yang kurang darah, dengan cara memakan daging anjing yang sudah dimasak. Daging anjing mengandung natrium yang tinggi sehingga dapat memicu hipertensi atau tekanan darah tinggi. Menurut Mahawar dan Jaroli (2006), anjing digunakan sebagai obat gatal dan sebagai obat sakit telinga.

\section{c. Beruang (Helarctos malayanus)}

Empedu beruang (Gambar 2) bermanfaat untuk mengobati penyakit dalam akibat jatuh, baik jatuh dari motor maupun jatuh dari pohon dan sebagainya. Pemanfaatan empedu beruang merupakan salah satu obat tradisional Suku Dayak Mayan yang tergolong manjur dan mujarap. Oleh sebab itu banyak orang yang mencarinya walaupun tidak mudah untuk mendapatkannya karena beruang adalah salah satu hewan yang buas dan garang. Cara pengolahannya sama seperti mengolah empedu hewan lain, yaitu dengan cara dikeringkan atau dijemur, setelah kering kemudian dilarutkan kedalam air dan langsung diminum. Empedu beruang memiliki kadar asam ursodeoxycholic (UDCA) yang tinggi dan zat asam ini berguna untuk mengobati berbagai masalah penyakit liver dan empedu.

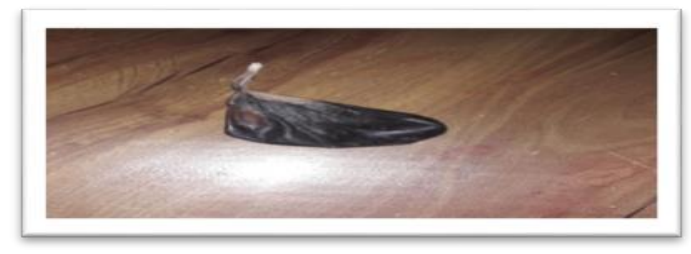

Gambar 2. Empedu Beruang (The Bear Bile)

\section{d. Tupai (Tupaia spp)}

Tupai adalah salah satu hewan yang dijadikan obat tradisional oleh Suku Dayak Mayan. Tupai dipercaya oleh masyarakat dapat mengobati diabetes, dengan cara memakan daging tupai yang sudah dimasak. Dalam 100 gram daging tupai terkandung 21.4 gram protein didalamnya. Protein merupakan zat yang dibutuhkan oleh tubuh kita karena berguna untuk keseimbangan tubuh, tempat untuk merambatnya impuls saraf, mengatur metabolisme tubuh dan sebagai bahan untuk terbentuknya enzim. Daging tupai juga dipercaya mempunyai kandungan lemak yang rendah dan kandungan mineral yang baik bagi tubuh. Masyarakat 
Dayak Seberuang di Desa Gurung Mali Kecamatan Tempunak Kabupaten Sintang percaya bahwa daging tupai memiliki khasiat untuk penambah stamina dan dipercaya mampu membantu proses penyembuhan bagi penderita diabetes. Daging tupai tidak mengandung kolesterol, sehingga cocok dikonsumsi oleh masyarakat yang peduli dengan kesehatannya.

e. Kelelawar

(Megachiroptera

Microchiroptera)

Kelelawar kecil atau microchiroptera biasanya hidup dan ditemukan di pohon pisang. Kelelawar ini dipercaya oleh masyarakat Dayak Mayan untuk mengobati asma. Cara pengolahannya kelelawar yang didapat dibersihkan terlebih dahulu, setelah itu dimasak dan cara pemakaiannya langsung dimakan. Ransalaleh (2013), kelelawar jenis $\mathrm{N}$. cephalotes dan $\mathrm{P}$. Alecto mengandung senyawa steroid kelompok estron dan androstan, dan alkaloid dengan kerangka piridinpiperidin dan imidazol. Khairat dkk., (2016) menyatakan alkaloid turunan piperidin dapat menyembuhkan asma. Senyawa piridin dengan Rumus Kimia C5H5N digunakan sebagai pelopor agrokimia dan obat-obatan dan juga penting sebagai larutan dan reagen. Pemanfaatan seluruh badan juga dilakukan pada hewan kelelawar atau dalam bahasa Dayak Belangin kala buluh dan dalam bahasa Dayak Kanayant Kaiawar buuh atau Myotis muricola namun tidak semua kelelawar kecil atau Kaiawar buuh dapat dijadikan obat hanya kelelawar atau Kaiawar buuh yang hidupnya di dalam batang bambu yang bermanfaat sebagai obat. Cara pengolahannya yaitu membersihkan kelelawar kecil atau Kaiawar buuh dari kotoran dan rambut halus kemudian merebus dengan menambah sedikit garam dapur. Penggunaannya dengan memakan kelelawar dan meminum airnya, hal ini dipercaya oleh masyarakat Dayak Belangin di Desa Mu'un dan masyarakat Dayak Kanayant di Desa Babane dapat menyembuhkan asma dan sakit kuning atau hepatitis.

\section{f. Ayam (Gallus gallus domesticus)}

Ayam selain dikonsumsi juga dimanfaatkan sebagai obat dan memiliki banyak manfaat. Dua organ tubuh ayam yang dapat dimanfaatkan sebagai obat tradisional yaitu daging (anak ayam) dan bulu. Daging (anak ayam) dicincang dicampur dengan serai dan nasi yang dibakar (Gambar 3) setelah itu ditempelkan ke bagian yang patah dan kemudian diikat, dipercaya oleh masyarakat Dayak Mayan untuk menyembuhkan patah tulang. Bulu ayam (Gambar 3) berfungsi menyembuhkan sakit mata atau yang biasa disebut masyarakat Dayak Mayan Petit. Cara pengobatannya yaitu darah yang ada pada benjolan merah yang terdapat dibagian luar belakang tubuh tersebut dikeluarkan terlebih dahulu kemudian dioles dengan darah dari bulu ayam yang diambil tersebut. Daging ayam mengandung nutrisi seperti protein yang tinggi yakni sebesar 18 gram dalam 100 gram daging ayam. Selain itu, daging ayam juga 
mengandung sejumlah nutrisi seperti kalsium, magnesium, fosfor, kalium, natrium, juga beberapa vitamin seperti vitamin $C$, vitamin $B 1$, vitamin $D$, vitamin $\mathrm{B}-12$, vitamin $\mathrm{A}$, vitamin $\mathrm{K}$, folat, juga riboflavin dan niacin. Manfaat daging ayam yaitu membantu pembentukan otot, meningkatkan metabolisme tubuh, mengatur kadar kolesterol, mengurangi gejala PMS, menghilangkan stres, merawat kesehatan kulit, membuang racun dalam
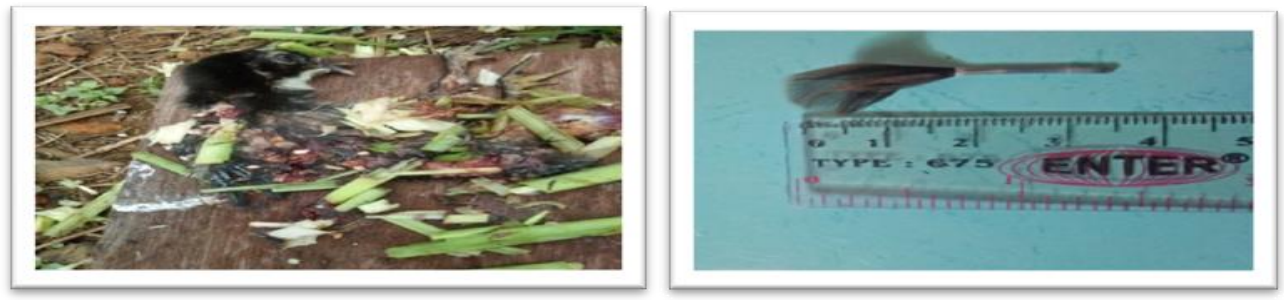

Gambar 3. Anak Ayam yang Dicincang dan Bulu Ayam (The Chopped Chicks and Chicken Feathers)

\section{g. Gabus (Channa striata)}

Gabus atau yang biasa disebut masyarakat Dayak Mayan ikan delak adalah termasuk jenis ikan yang hidup di air tawar. Daging ikan gabus yang sudah dimasak (direbus) dipercaya oleh masyarakat sangat bagus dikonsumsi untuk proses pemulihan (penyembuhan luka) setelah operasi. Ikan gabus memiliki daging yang kaya akan protein albumin. Protein yang ada di ikan gabus tersebut dapat membantu menyembuhkan luka setelah operasi dan juga dapat dengan cepat membuat selsel baru di dalam tubuh yang telah rusak karena bedah operasi. Masyarakat Dayak Bakati di Desa Seluas Kecamatan Seluas Kabupaten Bengkayang memanfaatkan ikan gabus untuk mengobati bekas luka operasi tubuh, mencegah alzheimer, mencegah dan mengatasi anemia, membantu menurunkan berat badan, mengurangi risiko radang sendi, baik untuk pertumbuhan anak, meningkatkan kesehatan jantung, menjaga kekuatan gigi dan meminimalisir risiko kanker. Bulu ayam memiliki kandungan asam amino utama yang meliputi serin, prolin, glisin, sistein, asam glutamat, leusin dan valin. 
menyembuhkan penyakit asma, penggunaan untuk dagingnya dengan cara memakan daging yang sudah dimasak (direbus) dan penggunaan untuk darahnya bisa langsung diminum mentah-mentah. Belut memiliki kandungan protein yang tinggi, sumber kalori yang baik bagi tubuh, kandungan zat besi yang baik untuk tubuh, sebagai sumber fosfor, kaya akan kandungan vitamin A dan vitamin B, memiliki kandungan arginin dan kandungan zat besi yang baik bagi kesehatan tubuh manusia. Menurut Masyarakat Dayak Seberuang di Desa Gurung Mali Kecamatan Tempunak Kabupaten Sintang, belut berguna untuk menyembuhkan kanker payudara dan meningkatkan kekebalan tubuh, dengan cara memakan belut yang sudah dipanggang di atas bara api. Masyarakat Dayak Seberuang biasa menyebut belut dengan bolut. Masyarakat Dayak Bakati di Desa Seluas Kecamatan Seluas Kabupaten Bengkayang memanfaatkan belut untuk konsumsi dan obat, menurut masyarakat belut merupakan hewan yang memiliki banyak darah, sehingga dimanfaatkan sebagai obat anemia atau kekurangan darah dengan cara pengolahan yaitu ditumis kemudian dimakan.

\section{i. Arwana (Scleropages formosus)}

Arwana atau yang biasa disebut oleh masyarakat Dayak Mayan ikan siluk biasanya dimanfaatkan untuk dijadikan peliharaan/hiasan. Secara umum yang orang ketahui manfaat siluk hanya dijadikan sebatas hiasan saja. Bagi masyarakat Dayak Mayan, siluk selain sebagai peliharaan, sisiknya juga bisa dimanfaatkan sebagai obat tradisional untuk menyembuhkan penyakit. Sisik ikan siluk (Gambar 4) berkhasiat untuk mengobati gigitan serangga. Cara penggunaannya yaitu sisiknya dibakar setelah itu dioles ke bagian yang digigit serangga. Tanpa disadari sisik ikan memiliki beberapa kandungan yang bisa dimanfaatkan. Komponen besar yang terdapat di sisik ikan antara lain adalah 70\% air, 27\% protein, $1 \%$ lemak dan $2 \%$ abu. Senyawa organik terdiri dari $40 \%-90 \%$ pada sisik ikan dan selebihnya merupakan kolagen, tanpa memperhatikan spesies ikan tersebut.

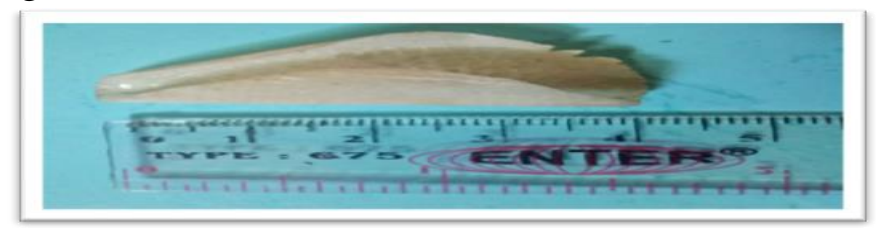

Gambar 4. Sisik Ikan Siluk (Arwana) (The Arowana Fish Scales)

\section{j. Biawak (Varanus salvator)}

Biawak atau yang biasa disebut oleh masyarakat Dayak Mayan bejawak adalah hewan yang dimanfaatkan untuk dikonsumsi. Kebanyakan yang orang ketahui manfaat bejawak hanya sebatas itu saja. Ketika melakukan wawancara dengan 2 orang responden, mereka menjelaskan bahwa manfaat bejawak selain untuk dikonsumsi, dagingnya bisa dijadikan sebagai obat tradisional. Daging bejawak dipercaya oleh masyarakat dapat 
mengobati penyakit kulit seperti gatalgatal dan bisul, dengan cara memakan daging bejawak yang sudah dimasak (direbus). Menurut Iyai dkk., (2011), pemanfaatan hewan seperti Biawak digunakan oleh Suku Yaur di Papua sebagai minyak pijat dan obat tradisional. Empedu merupakan bagian organ tubuh hewan yang dimanfaatkan sebagai obat oleh Masyarakat Dayak Belangin di Desa Mu'un. Hewan yang dimanfaatkan empedunya yaitu biawak. Empedu biawak dipercaya dapat mengobati berbagai jenis penyakit seperti asma, flu dan gigitan hewan berbisa seperti ular, kalajengking, sengatan lebah dan hewan lainnya. Hal ini tidak jauh berbeda dengan penelitian Novriyanti dkk (2014) pada Orang Rimba di Bukit Duabelas Provinsi Jambi yang memanfaatkan empedu biawak sebagai obat sakit mata, mata merah dan sakit perut. Cara penggunaan empedu sebagai obat berbeda tergantung dari jenis penyakit, apabila penyakit dalam maka penggunaannya diminum dengan mencampurkan empedu dengan air hangat dan apabila penyakit luar penggunaannya dioleskan pada bagian yang sakit.

\section{k. Ular Pithon (Python reticulatus)}

Ular Pithon atau yang biasa disebut oleh masyarakat Dayak Mayan ulah sawak adalah jenis hewan melata dan tidak sedikit orang yang takut terhadap hewan melata satu ini. Meskipun demikian, berdasarkan wawancara saya dengan seorang responden, Beliau mengatakan lemak ulah sawak (Gambar 5) bisa dimanfaatkan untuk mengobati alergi kulit seperti gatal dan korengan. Cara pengolahannya yaitu dengan cara dijemur sampai lemak ular tersebut menjadi minyak dan cara penggunaannya yaitu lemak ular yang sudah menjadi minyak tersebut dioles ke bagian kulit yang gatal dan korengan. Manfaat lain dari ular adalah minyaknya. Minyak dapat bereaksi dengan segera setelah diolesi ke bagian kulit yang alergi. Minyak ini mampu untuk mengatasi gigitan serangga yang menimbulkan bengkak pada kulit dan minyak ini juga bermanfaat mengatasi serangan herpes sebelum melebar. Pemanfaatan lain organ tubuh hewan ialah lemak. Masyarakat Dayak Belangin di Desa Mu'un dan Masyarakat Dayak Kanayant di Desa Babane menggunakan lemak ular pithon atau dalam bahasa Dayak Belangin ula sawa dan dalam bahasa Dayak Kanayant uwar sawa sebagai minyak urut. Minyak urut yang terbuat dari lemak ular pithon dipercaya dapat mengatasi sakit badan dan memar akibat benturan atau sakit pegal-pegal. Salah satu bagian satwa yang digunakan Masyarakat Dayak Bakati di Desa Seluas Kecamatan Seluas Kabupaten Bengkayang untuk pengobatan yaitu lemak dari ular pithon atau nipa pangganun untuk menyembuhkan sakit badan atau pegal-pegal. Hal ini didukung oleh (Putra, 2008) mengatakan Jenis bahan lain dari satwa yang juga sering dimanfaatkan masyarakat adalah lemak. Sebagian besar penggunaan lemak adalah untuk memperoleh minyak yang dapat digunakan sebagai minyak urut. 


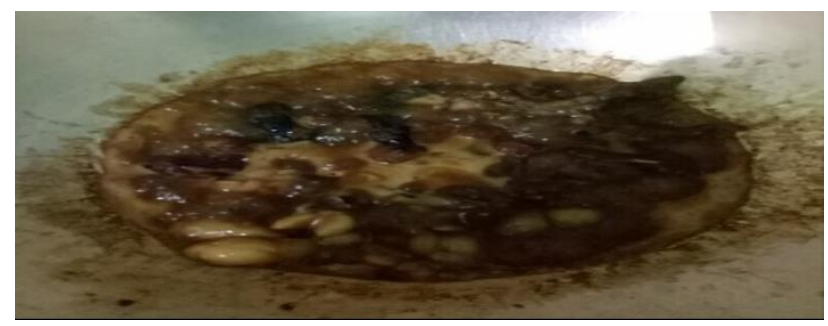

Gambar 5. Lemak Ular Sawak (Pithon) (The Pithon Snake Fat)

\section{Ular Tedung (Ptyas korros)}

Ular Tedung atau yang biasa disebut oleh masyarakat Dayak Mayan ulah hipung hampir sama dengan ular pithon jenisnya tetapi bedanya kalau ular pithon ukurannya panjang sedangkan ulah hipung ukurannya relatif lebih pendek. Kalau ular pithon yang dimanfaatkan lemaknya, berbeda dengan ulah hipung yang dimanfaatkan oleh masyarakat yaitu dagingnya. Daging ulah hipung dimanfaatkan oleh masyarakat untuk mengobati alergi kulit seperti gatal dengan cara memakan daging ulah hipung yang sudah dimasak. Daging biasa dipakai untuk mengobati eksim, sejenis penyakit yang dicirikan dengan gatal-gatal di permukaan kulit. Tulang merupakan salah satu bagian dari hewan yang dimanfaatkan oleh Masyarakat di Desa Mu'un dan Masyarakat di Desa Babane namun tidak semua jenis tulang dimanfaatkan. Tulang-tulang tertentu yang mereka gunakan yaitu tulang ular tedung. Tulang ular tedung atau dalam bahasa Dayak Belangin disebut Ula dan dalam bahasa Dayak Kanayant disebut uwar dipercaya dapat mengobati sakit pinggang dan cara pengolahannya sangat mudah yaitu dengan membakar tulang ular tedung kemudian ditumbuk setelah itu diberi air hangat dan penggunaannya diminum.

\section{m.Lebah Madu (Apis spp)}

Lebah Madu atau yang biasa disebut oleh masyarakat Dayak Mayan muanyik yang dimanfaatkan sebagai obat adalah madunya. Meminum madu yang diperas langsung dari sarangnya dipercaya oleh masyarakat untuk mengobati orang sakit akibat jatuh, baik jatuh dari motor maupun jatuh dari pohon dan sebagainya. Madu selain mengobati orang sakit akibat jatuh, juga dimanfaatkan sebagai obat tradisional untuk menyembuhkan batuk, dengan cara ambil madu yang terdapat pada sarangnya kemudian madu diambil sesendok dicampur jeruk nipis dan langsung diminum. Madu yang memiliki rasa manis memiliki banyak kandungan alami, seperti antioksidan dan nutrisi lainnya yang baik untuk tubuh. Madu adalah sumber karbohidrat yang baik untuk tubuh. Nektar yang merupakan bahan utama pembentuk madu terdiri dari sukrosa dan air. Lebah menambahkan enzim yang menciptakan senyawa kimia tambahan dan nilai gizi madu sehingga menjadi karbohidrat. Kandungan ini lah yang membuat madu sangat baik dikonsumsi untuk penambah energi. Madu kaya akan gula alami sehingga baik untuk penambah 
rasa karena mengandung $80 \%$ gula alami yang terdiri dari fruktosa dan glukosa. Madu mengandung air untuk melembapkan, semakin sedikit kandungan air pada madu, maka akan semakin baik nilai gizinya. Selain bermanfaat untuk kesehatan organ dalam tubuh, kandungan mineral dan vitamin pada madu baik untuk metabolisme sistem tubuh. Madu memiliki kandungan kalori yang seimbang untuk tubuh. Madu memiliki Glycemic Index (GI) berarti gula atau pemanis dalam madu dapat secara bertahap diserap ke dalam aliran darah untuk membantu proses pencernaan menjadi lebih baik.

\section{n. Cacing Tanah (Lumbricus spp)}

Cacing Tanah atau yang disebut oleh masyarakat Dayak Mayan cacin tanah adalah hewan yang biasa dimanfaatkan untuk dijadikan umpan pancing saat memancing. Kebanyakan orang hanya mengetahui manfaat cacing tanah hanya sebatas itu saja. Ketika melakukan wawancara dengan seorang responden, beliau menjelaskan bahwa kulit cacing tanah bisa menyembuhkan penyakit. Kulit cacing tanah berkhasiat untuk menyembuhkan penyakit asma dengan cara memakan kulit cacing yang sudah dibersihkan dan digoreng. Perlu diketahui bahwa kadar protein dan asam amino pada hewan cacing cukup tinggi. Selain protein dan asam amino yang sangat tinggi, cacing tanah juga mengandung vitamin, zat besi dan kalsium dengan konsentrasi yang cukup tinggi. Tak hanya itu, cacing tanah juga memiliki sistem kekebalan tubuh yang bersifat antimikroba, sehingga para pakar ahli kesehatan menilai bahwa cacing tanah sangat berguna untuk melawan berbagai mikroba yang menyebabkan berbagai masalah kesehatan di dalam tubuh kita. Manfaat satwa sebagai obat oleh Masyarakat Dayak Seberuang di Desa Gurung Mali Kecamatan Tempunak Kabupaten Sintang untuk seluruh badan yaitu cacing tanah. Cacing tanah banyak menyimpan manfaat dikenal sebagai obat tipes. Cara pengolahannya yaitu cacing dibersihkan dan direbus hingga mendidih dengan 3 gelas air untuk ukuran diminum 3 kali sehari, kemudian disaring dan ambil airnya, dinginkan sebentar atau minum hangat-hangat.

\section{KESIMPULAN}

Berdasarkan hasil analisis yang telah dilakukan dapat disimpulkan bahwa jumlah jenis hewan atau satwa yang dimanfaatkan oleh Masyarakat Dayak Mayan untuk obat yaitu 14 spesies. Bagian tubuh hewan yang dimanfaatkan untuk pengobatan adalah duri, daging, empedu, bulu, darah, sisik, lemak, madu dan kulit. Pengolahannya dengan cara diambil, dimasak (direbus dan digoreng), dikeringkan (dijemur), dicincang, dibakar dan diperas, sementara pemanfaatannya dengan cara ditancap di sungai, dimakan, diminum, ditempel ke bagian yang patah dan dioles.

\section{SARAN}

Perlu dilakukan penelitian lebih lanjut mengenai hewan atau satwa yang bermanfaat sebagai obat tradisional masyarakat untuk mengetahui 
kandungan yang terdapat pada hewan atau satwa tersebut. Kurangnya informasi atau sedikitnya pengetahuan masyarakat mengenai status perlindungan hewan atau satwa yang hampir punah sehingga diperlukan sosialisasi kepada masyarakat gunanya agar masyarakat bisa mengetahui karena selama ini belum pernah adanya sosialisasi langsung terhadap Masyarakat Dayak Mayan di Desa Mensusai Kecamatan Suhaid Kabupaten Kapuas Hulu.

\section{UCAPAN TERIMA KASIH}

Penulis mengucapkan banyak terima kasih kepada Kepala Desa Mensusai, Kecamatan Suhaid, Kabupaten Kapuas Hulu yang telah memberikan ijin kepada penulis untuk melakukan penelitian di desa tersebut.

\section{DAFTAR PUSTAKA}

Iyai DA, Murwanto AG dan Killian AM. (2011). Sistem Perburuan dan Etnozoologi Biawak (Famili Varanidae) oleh Suku Yaur pada Taman Nasional Laut Teluk Cenderawasih. Jurnal Biota 16 (2).

Mahawar MM dan Jaroli DP. 2006. Animals and Their products utilized as medicines by the inhabitans surrounding the Ranthambhore National Park, India. Journal of Ethnobiology and Ethomedicine 2:46.
Maria H, Anwari MS dan Yani A. 2018. Kajian Etnozoologi Untuk Obatobatan Masyarakat Dayak Belangin di Desa Mu'un Kecamatan Ngabang Kabupaten Landak. Jurnal Hutan Lestari 6 (3) : $647-653$.

Novriyanti, Masy'ud B dan Bismar M. 2014. Pola dan Nilai Lokal Etnis dalam Pemanfaatan Satwa pada Orang Rimba Bukit Duabelas Provinsi Jambi. Penelitian Hutan dan Konservasi Alam (11) : 299301.

Poerwandi EK. 1998. Metode Penelitian Sosial. Universitas Terbuka : Jakarta.

Putra YAE, Masy'ud B dan Ulfah M. 2008. Keanekaragaman Satwa Berkhasiat Obat di Taman Nasional Betung Kerihun, Kalimantan Barat Indonesia. Media Konservasi. 13 (1) : 8-15.

Ransalaleh. TA. 2013. Identifikasi Morfologi Karakteristik dan Ekstraksi Komponen Bioaktif Daging Kelelawar di Sulawesi Sebagai Bahan Pangan . Institut Pertanian Bogor. Bogor.

Ruly DK, Ardian H dan Anwari MS. 2019. Kajian Etnozoologi Untuk Pengobatan Suku Dayak Sebaruk di Desa Setunggul Kecamatan Silat Hilir Kabupaten Kapuas Hulu. Jurnal Hutan Lestari 7 (3) : $1282-1289$. 